\title{
Periodate Oxidation of a Ternary Complex of Nitrilotriacetatochromium(III) Involving ß-Alanine as Co-Ligand
}

\author{
Hassan A. Ewais ${ }^{1 *}$, Ahmed H. Abdel-Salam², Amal S. Basaleh¹, Mohamed A. Habib ${ }^{3}$ \\ ${ }^{1}$ Chemistry Department, Faculty of Science, King Abdulaziz University, Jeddah, KSA \\ ${ }^{2}$ Chemistry Department, Faculty of Science, University of Jeddah, Jeddah, KSA \\ ${ }^{3}$ Chemistry Department Faculty of Science, Al-Tahadi University, Serit, Lybia \\ Email: *ahmedhassan179@yahoo.com
}

How to cite this paper: Ewais, H.A., Abdel-Salam, A.H., Basaleh, A.S. and Habib, M.A. (2018) Periodate Oxidation of a Ternary Complex of Nitrilotriacetatochromium(III) Involving ß-Alanine as Co-Ligand. Open Journal of Inorganic Chemistry, 8, 91-104. https://doi.org/10.4236/ojic.2018.84008

Received: September 5, 2018

Accepted: October 12, 2018

Published: October 15, 2018

Copyright $\odot 2018$ by authors and Scientific Research Publishing Inc. This work is licensed under the Creative Commons Attribution International License (CC BY 4.0).

http://creativecommons.org/licenses/by/4.0/

\section{Open Access}

\begin{abstract}
The kinetics of the periodate oxidation of chromium(III)-complex, $\left[\mathrm{Cr}^{\mathrm{III}}(\mathrm{NTA})(\mathrm{Ala})\left(\mathrm{H}_{2} \mathrm{O}\right)\right]-(\mathrm{NTA}=$ Nitrilotriacetate and $\mathrm{Ala}=\mathrm{B}$-alanine $)$ to $\mathrm{Cr}(\mathrm{VI})$ have been carried out for the temperature range $15^{\circ} \mathrm{C}-35^{\circ} \mathrm{C}$ under pseudo-first order conditions, $\left[\mathrm{IO}_{4}^{-}\right] \gg[$ complex]. Reaction obeyed first order dependence with respect to $\left[\mathrm{IO}_{4}^{-}\right]$and $[\mathrm{Cr}(\mathrm{III})]$, and the rate of reaction increases with increasing of $\mathrm{pH}$ for the range 3.40 - 4.45. Experimentally, the mechanism of this reaction is found to be consistent with the rate law in which the hydroxo species, $\left[\mathrm{Cr}{ }^{\mathrm{III}}(\mathrm{NTA})(\mathrm{Ala})(\mathrm{OH})\right]^{2-}$ is considerably much more reactive than their conjugate acid. $\Delta H^{\star}$ and $\Delta S^{\star}$ have been calculated. It is proposed that electron transfer occurs through an inner-sphere mechanism via coordination of $\mathrm{IO}_{4}^{-}$to chromium(III).
\end{abstract}

\section{Keywords}

Nitrilotriacetatochromium(III), Ternary Complex, Periodate Oxidation, Inner-Sphere Mechanism, Thermodynamic Activation Parameters

\section{Introduction}

The Ternary complexes of oxygen-donor ligands and heteroaromatic N-bases such as nitrilotriacetic acid (NTA) and iminodiacetic acid (IDA) with transition metals have attracted much interest, as they can display exceptionally high stability and may be biologically relevant [1] [2]. The use of transition metal complexes of NTA is gaining increasing use in biotechnology, particularly in the 
protein purification technique known as immobilized metal-ion chromatography [3]. The chromium(III) complexes of $a$ amino acids are biologically available, depending on the complexing ability of the ligands for chromium against $\mathrm{OH}^{-}$. Chromium can also aid in the transportation of amino acids through the cell membrane [4]. The biological oxidation of chromium from the trivalent to the hexavalent state is an important environmental process because of the high mobility and toxicity of chromium(VI) [5]. Recently, $\mathrm{Cr}(\mathrm{III})$ oxidation to $\mathrm{Cr}(\mathrm{V})$ and/or $\mathrm{Cr}(\mathrm{VI})$ in biological systems came into consideration as a possible reason for the anti-diabetic activities of some $\mathrm{Cr}$ (III) complexes, as well as the long-term toxicities of such complexes [6]. The specific interactions of chromium ions with cellular insulin receptors [7] are a consequence of intra- or extracellular oxidations of $\mathrm{Cr}(\mathrm{III})$ to $\mathrm{Cr}(\mathrm{V})$ and/or $\mathrm{Cr}(\mathrm{VI})$ compounds, which act as protein tyrosine phosphatase (PTP) inhibitors. Periodate oxidations have been reported to play an important role in biological processes [8] [9] [10].

Studies of the kinetics of periodate oxidations on a series of dextran oligomers, polymers and some dimeric carbohydrates [8] revealed a dependence of the kinetic rates on the molecular weight. The oxidation of caffeic acid (3,4-dihydroxy cinnamic acid) by sodium periodate was found to mimic the mechanism of polyphenol oxidase. The antioxidant product 2-s-cysteinyl caffeic acid exhibits slightly improved antiradical activity compared to the parent molecule (caffeic acid) [9]. The imidazol-modified M-salophen/ $/ \mathrm{NaIO}_{4}$ system can be applied to oxidize a large number of primary aromatic amines in good yield at short times and room temperature [10].

An inner-sphere mechanism for oxidation of chromium(III) complexes of some amino acids [11] [12] [13] and nucleosides [14] [15] [16] by periodate has been proposed with the hydroxo group acting as bridging ligand, or through the substitution of coordinated $\mathrm{H}_{2} \mathrm{O}$ by $\left[\mathrm{IO}_{4}\right]^{-}$. Oxidation of ternary nitrilotriacetatocobalt(II) complexes involving succinate, malonate, tartrate, maleate and benzoate as secondary ligands by periodate has been investigated [17] [18] [19]. In all cases, initial cobalt(III) products were formed, and these changed slowly to the final cobalt(III) products. It is proposed that the reaction follows an inner-sphere mechanism, involving a ring closure step that is faster than the oxidation step. The $\mathrm{I}^{\mathrm{VI}}$ in the initial product is probably substitutional by water at a very slow rate due to the substituted inertness of $\mathrm{Co}$ (III) and also the $\mathrm{Co}(\mathrm{II})-\mathrm{OIO}_{3}$ bond being stronger than $\mathrm{Co}-\mathrm{H}_{2} \mathrm{O}$ bond. The oxidation of cobalt(II) complexes of propylenediaminetetraacetate (PDTA) [20], 1,3-diamino-2-hydroxypropanetetraacetate (HPDTA) [20], diethylenetriamine-pentaacetate (DPTA) [21], trimethylenediaminetetraacetate (TMDTA) [22] and ethyleneglycol,bis(2-aminoethyl)ether,N,N,N0,N0-tetraacetate (EGTA) [22] by periodate gave only the final product. Periodate oxidations of the chromium(III) complexes of NTA [23], 2-aminopyridine [24] and IDA [25] were studied. In all cases, the electron transfer proceeds through an inner-sphere mechanism via coordination of $\mathrm{IO}_{4}^{-}$to chromium(III). 
In this paper, we report on the kinetics and mechanism of the periodate oxidation of ternary complexes of chromium(III) involving NTA as primary ligand and $B$-alanine as a secondary ligand, in order to study the effect of secondary ligand on the stability of $\left[\mathrm{Cr}^{\mathrm{III}}(\mathrm{NTA})(\mathrm{Ala})\left(\mathrm{H}_{2} \mathrm{O}\right)\right]^{-}[23]$ toward oxidation.

\section{Experimental}

\subsection{Materials and Methods}

The ternary complexes of chromium(III) involving nitrilotriacetato and $\beta$-alanine was prepared according to the report method [26]. All chemicals used in this study were of analar grade (BDH, Aldrich and Sigma). Buffer solutions were prepared from $\mathrm{CH}_{3} \mathrm{COONa}$ (Sigma 99\%) and $\mathrm{CH}_{3} \mathrm{COOH}$ (BHD 99.9\%) of known concentration. $\mathrm{NaNO}_{3}$ (Aldrich 99.99\%) was used to adjust ionic strength in the different buffered solutions. Doubly distilled $\mathrm{H}_{2} \mathrm{O}$ was used in all kinetic runs. A stock solution of $\mathrm{NaIO}_{4}$ (Aldrich 99.9\%) was prepared by accurate weighing and wrapped in aluminum foil to avoid photochemical decomposition [27].

\subsection{Instrumentation}

UV-vis spectrophotometer model JASCO UV-530 was used to record the electronic spectra of the investigated complexes. The oxidation of complex, $\left[\mathrm{Cr}^{\mathrm{III}}(\mathrm{NTA})(\mathrm{Ala})\left(\mathrm{H}_{2} \mathrm{O}\right)\right]^{-}$by $\mathrm{IO}_{4}^{-}$were followed spectrophotometrically. The absorption measurements for the oxidation of reaction products are maximum at the reaction $\mathrm{pH}$. Automatic circulation thermostat was used to regulate the temperature of solution. The average stabilizing accuracy was $\pm 0.1^{\circ} \mathrm{C}$. Large excess of $\mathrm{IO}_{4}^{-}$(>10-fold) was used in all measurements to get the pseudo-first order situation. $\mathrm{NaNO}_{3}$ solution was utilized to make a constant ionic strength. It is noticed that during the course of the reaction the $\mathrm{pH}$ of the reaction is constant.

\subsection{Kinetic Measurements}

The UV-Visible absorption spectra of the products of oxidation of the complex $\left[\mathrm{Cr}{ }^{\text {III }}(\mathrm{NTA})(\mathrm{Ala})\left(\mathrm{H}_{2} \mathrm{O}\right)\right]^{-}$by $\mathrm{IO}_{4}^{-}$was followed spectrophotometrically for a measured period of time using a JASCO UV-530 spectrophotometer. All reactants were thermally equilibrated for ca $15 \mathrm{~min}$ in an automatic circulation thermostat, then mixed thoroughly and quickly transferred to an absorption cell. The oxidation rates were measured by monitoring the absorbance of $\mathrm{Cr}(\mathrm{VI})$ at $350 \mathrm{~nm}$, on a Jenway 3600 spectrophotometer, where the absorption of the oxidation products is maximal at the reaction $\mathrm{pH}$. The $\mathrm{pH}$ of the reaction mixture was measured using a G-C825 pH-meter. Pseudo-first-order conditions were maintained in all runs by maintaining a large excess ( $>10$-fold) of $\mathrm{IO}_{4}^{-}$over complexes. The ionic strength was kept constant by the addition of $\mathrm{NaNO}_{3}$ solution. The $\mathrm{pH}$ of the reaction mixture was found to be constant during the reaction runs. Potentiometric measurements were performed with a Metrohm 702 
SM titrino, using Irving and Rossotti techniques [28].

\section{Results and Discussion}

The UV-Visible spectra of the oxidation product of the complex, $\left[\mathrm{Cr}^{\mathrm{III}}(\mathrm{NTA})(\mathrm{Ala})\left(\mathrm{H}_{2} \mathrm{O}\right)\right]^{-}$by periodate were recorded over time on a JASCO UV-530 spectrophotometer (Figure 1). The spectrum gives a maxima at 564 and $410 \mathrm{~nm}$ for $\left[\mathrm{Cr}^{\mathrm{III}}(\mathrm{NTA})(\mathrm{Ala})\left(\mathrm{H}_{2} \mathrm{O}\right)\right]^{-}$complex which disappeared and replaced by a single peak at $350 \mathrm{~nm}$ due to the formation of chromium (VI). The presence of one isosbestic point at $501 \mathrm{~nm}$ in the absorption spectra (Figure 1) indicates the presence of two absorbing species in equilibrium. To measure the stoichiometry, a known excess of $\mathrm{Cr}$ (III) complex was added to $\mathrm{IO}_{4}^{-}$solution and the absorbance of $\mathrm{Cr}(\mathrm{VI})$ produced was measured at $350 \mathrm{~nm}$ after $24 \mathrm{~h}$. The quantity of $\mathrm{Cr}$ (III) consumed was calculated using the molar absorptivity of $\mathrm{Cr}(\mathrm{VI})$ at the utilized $\mathrm{pH}$.

The oxidation of $\left[\mathrm{Cr}^{\mathrm{III}}(\mathrm{NTA})(\mathrm{Ala})\left(\mathrm{H}_{2} \mathrm{O}\right)\right]$-complex by periodate was carried out in the $\mathrm{pH}$ range $3.40-4.45,0.2 \mathrm{M}$ ionic strength, $\left[\mathrm{IO}_{4}^{-}\right]$range $(0.5-5.0) \times$ $10^{-2} \mathrm{M}$ and with temperature range $15^{\circ} \mathrm{C}-35^{\circ} \mathrm{C}\left( \pm 0.1^{\circ} \mathrm{C}\right)$. The stoichiometry of the reaction can be represented by Equation (1):

$$
2 \mathrm{Cr}(\mathrm{III})+3 \mathrm{I}(\mathrm{VII}) \rightarrow 2 \mathrm{Cr}(\mathrm{VI})+3 \mathrm{I}(\mathrm{V})
$$

where $\mathrm{Cr}$ (III) and I(VII) represent total chromium(III)-complex and periodate, respectively. The concentration ratio of $\mathrm{IO}_{4}^{-}$initially present to $\mathrm{Cr}(\mathrm{VI})$

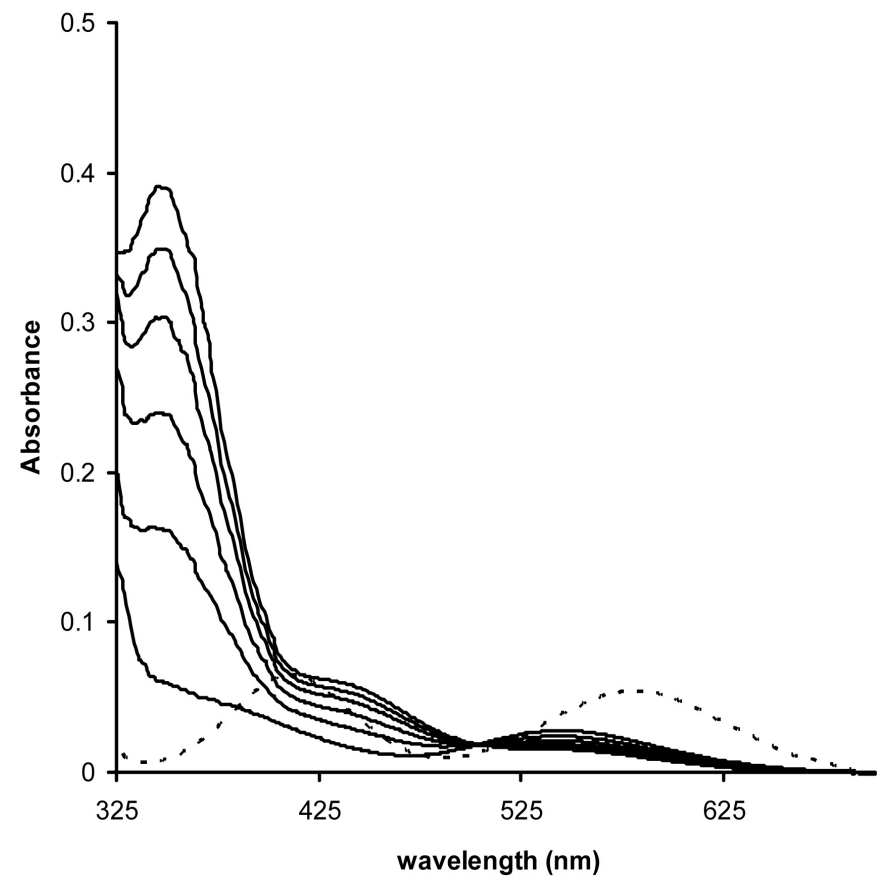

Figure 1. Absorbance spectra of reaction mixtures at interval times; [complex $]=2.5 \times 10^{-4} \mathrm{~mol} \cdot \mathrm{dm}^{-3},\left[\mathrm{IO}_{4}^{-}\right]=0.02 \mathrm{~mol} \cdot \mathrm{dm}^{-3}, I=0.2$ $\mathrm{mol} \cdot \mathrm{dm}^{-3}, \mathrm{pH}=4.05$ and $T=30^{\circ} \mathrm{C}$. Curve $(\cdots \cdots \cdots \cdots)$ spectrum of the complex $\left(2.5 \times 10^{-4} \mathrm{~mol} \cdot \mathrm{dm}^{-3}\right)$ at the same $\mathrm{pH}$. 
produced was found to be 3:2. The stoichiometry is also consistent with the observation that $\mathrm{IO}_{3}^{-}$does not oxidize the $\mathrm{Cr}(\mathrm{III})$-complex over the studied $\mathrm{pH}$ range. Table 1 shows pseudo-first order rate constants, $k_{\text {obs }}$. Data obtained exhibits that $k_{\text {obs }}$ does not have any effect, when we change the concentration of $\left[\mathrm{Cr}{ }^{\mathrm{III}}(\mathrm{NTA})(\mathrm{Ala})\left(\mathrm{H}_{2} \mathrm{O}\right)\right]^{-}$complex with constant $\mathrm{IO}_{4}^{-}$concentration of $2.0 \times$ $10^{-2} \mathrm{~mol} \cdot \mathrm{dm}^{-3}, \mathrm{pH}=4.05$, ionic strength $0.20 \mathrm{~mol} \cdot \mathrm{dm}^{-3}$, temperature $25^{\circ} \mathrm{C}$ and at different concentrations of complex over the range $(1.25-6.25) \times 10^{-4} \mathrm{~mol} \cdot \mathrm{dm}^{-3}$, confirming that this reaction is first order and related to the concentration of $\mathrm{Cr}(\mathrm{III})$ complex, $\left[\mathrm{Cr}^{\mathrm{III}}(\mathrm{NTA})(\mathrm{Ala})\left(\mathrm{H}_{2} \mathrm{O}\right)\right]^{-}$. This behavior is represented by Equation (2).

$$
\text { Rate }=k_{\text {obs }}\left[\mathrm{Cr}^{\text {III }}(\mathrm{NTA})(\mathrm{Ala})\left(\mathrm{H}_{2} \mathrm{O}\right)\right]^{-}
$$

The effect of periodate on the rate of the reaction of $\left.\mathrm{Cr}^{\mathrm{III}}(\mathrm{NTA})(\mathrm{Ala})\left(\mathrm{H}_{2} \mathrm{O}\right)\right]^{-}$ was studied over the temperature range $\left(15^{\circ} \mathrm{C}-35^{\circ} \mathrm{C}\right)$. The variation of rate constant, $k_{\mathrm{obs}}$, with different concentrations of $\left[\mathrm{IO}_{4}^{-}\right]$at different temperatures are summarized in Table 1. Plotting $k_{\mathrm{obs}}$ against $\left[\mathrm{IO}_{4}^{-}\right]$, was found to be linear without intercept as shown in Figure 2. The dependence of $k_{\text {obs }}$ on $\left[\mathrm{IO}_{4}^{-}\right]$is thus described by Equation (3):

$$
k_{\mathrm{obs}}=k_{1}\left[\mathrm{IO}_{4}^{-}\right]
$$

The dependence of the reaction rate on $\mathrm{pH}$ was investigated over the $3.40-4.45$ $\mathrm{pH}$ range at constant $\left[\mathrm{IO}_{4}^{-}\right]=2.0 \times 10^{-2} \mathrm{~mol} \cdot \mathrm{dm}^{-3},\left[\mathrm{Cr}{ }^{\mathrm{III}}(\mathrm{NTA})(\mathrm{Ala})\left(\mathrm{H}_{2} \mathrm{O}\right)\right]^{-}=$ $2.5 \times 10^{-4} \mathrm{~mol} \cdot \mathrm{dm}^{-3}, I=0.20 \mathrm{~mol} \cdot \mathrm{dm}^{-3}$ and $T=25^{\circ} \mathrm{C}$. The kinetic data are graphically represented in Figure 3 . Variation of the $k_{\mathrm{obs}}$ with $\mathrm{pH}$ is summarized in (Table 2), which indicates that the reaction rate increases with increasing $\mathrm{pH}$ values. Plot of $k_{\mathrm{obs}}$ against $\left[\mathrm{IO}_{4}^{-}\right]$at different $\mathrm{pH}$ values are given in Figure 3. From Figure 3, it was found that, the slopes are dependent on $\mathrm{pH}$ (Table 3 ). Plot of these slopes $\left(k_{1}\right)$ versus $1 / \mathrm{H}^{+}$are linear with slope $\left(k_{3}\right)$ and an intercept $\left(k_{2}\right)$ according to Equation (4).

$$
k_{1}=k_{2}+k_{3} /\left[\mathrm{H}^{+}\right]
$$

Table 1. Dependence of $k_{\mathrm{obs}}$ on $\left[\mathrm{IO}_{4}^{-}\right]$at $\mathrm{pH}=4.05,\left[\mathrm{Cr}^{\mathrm{III}}(\mathrm{NTA})(\mathrm{Ala})\left(\mathrm{H}_{2} \mathrm{O}\right)\right]^{-\mathrm{a}}=2.5 \times$ $10^{-4} \mathrm{~mol} \cdot \mathrm{dm}^{-3}$, and $I=0.2 \mathrm{~mol} \cdot \mathrm{dm}^{-3}$ at different temperatures.

\begin{tabular}{cccccc}
\hline $10^{2}\left[\mathrm{IO}_{4}^{-}\right]\left(\mathrm{mol}^{\circ} \cdot \mathrm{dm}^{-3}\right)$ & $10^{4} k_{\mathrm{obs}}\left(\mathrm{s}^{-1}\right) 15^{\circ} \mathrm{C}$ & $20^{\circ} \mathrm{C}$ & $25^{\circ} \mathrm{C}$ & $30^{\circ} \mathrm{C}$ & $35^{\circ} \mathrm{C}$ \\
\hline 0.5 & 0.500 & 0.88 & 1.20 & 1.51 & 2.31 \\
1.0 & 1.25 & 1.95 & 2.96 & 3.48 & 6.23 \\
1.5 & 2.51 & 3.25 & 4.15 & 4.81 & 8.50 \\
2.0 & 2.98 & 4.5 & 5.65 & 6.33 & 12.00 \\
3.0 & 4.46 & 6.68 & 8.31 & 10.15 & 13.50 \\
4.0 & - & 8.80 & 9.86 & 12.25 & - \\
5.0 & 7.25 & 10.20 & 12.75 & - & 20.05 \\
\hline
\end{tabular}


Table 2. Effect of $\mathrm{pH}$ on $k_{\text {obs }}$ at $\left[\mathrm{Cr}^{\mathrm{III}}(\mathrm{NTA})(\mathrm{Ala})\left(\mathrm{H}_{2} \mathrm{O}\right)\right]^{-}=2.5 \times 10^{-4} \mathrm{~mol} \cdot \mathrm{dm}^{-3}, I=0.2$ $\mathrm{mol} \cdot \mathrm{dm}^{-3}$, and $T=25^{\circ} \mathrm{C}$.

\begin{tabular}{cccccc}
\hline $\begin{array}{c}10^{2}\left[\mathrm{IO}_{4}^{-}\right] \\
\left(\mathrm{mol} \cdot \mathrm{dm}^{-3}\right)\end{array}$ & $\begin{array}{c}10^{4} k_{\text {obs }}\left(\mathrm{s}^{-1}\right) \\
\mathrm{pH}=3.40\end{array}$ & $\mathrm{pH}=3.72$ & $\mathrm{pH}=4.05$ & $\mathrm{pH}=4.27$ & $\mathrm{pH}=4.45$ \\
\hline 0.5 & 0.66 & 0.83 & 1.20 & 1.66 & 3.60 \\
1.0 & 0.88 & 1.51 & 2.96 & 5.51 & - \\
1.5 & 1.20 & 2.28 & 4.14 & 6.4 & 8.45 \\
2.0 & 1.58 & 2.66 & 5.65 & 10.51 & 12.16 \\
3.0 & 2.95 & 4.01 & 8.31 & 15.5 & 19.01 \\
4.0 & 4.16 & 5.66 & 9.86 & 19.03 & 22.56 \\
5.0 & 5.00 & 7.58 & 12.75 & 23.68 & 31.20 \\
\hline
\end{tabular}

Table 3. Values of $\left(k_{1}\right)$ at different temperatures.

\begin{tabular}{cccc}
\hline$T\left({ }^{\circ} \mathrm{C}\right)$ & $10^{3} / T\left(\mathrm{~K}^{-1}\right)$ & $10^{2} k_{1}\left(\mathrm{~mol}^{-1} \cdot \mathrm{dm}^{3} \cdot \mathrm{s}^{-1}\right)$ & $-\ln k_{1} / T\left(\mathrm{~mol}^{-1} \cdot \mathrm{dm}^{3} \cdot \mathrm{s}^{-1} \cdot \mathrm{K}^{-1}\right)$ \\
\hline 15 & 3.47 & 1.42 & 9.92 \\
20 & 3.41 & 2.13 & 9.53 \\
25 & 3.35 & 2.64 & 9.33 \\
30 & 3.30 & 3.21 & 9.15 \\
35 & 3.25 & 4.05 & 8.93 \\
\hline
\end{tabular}

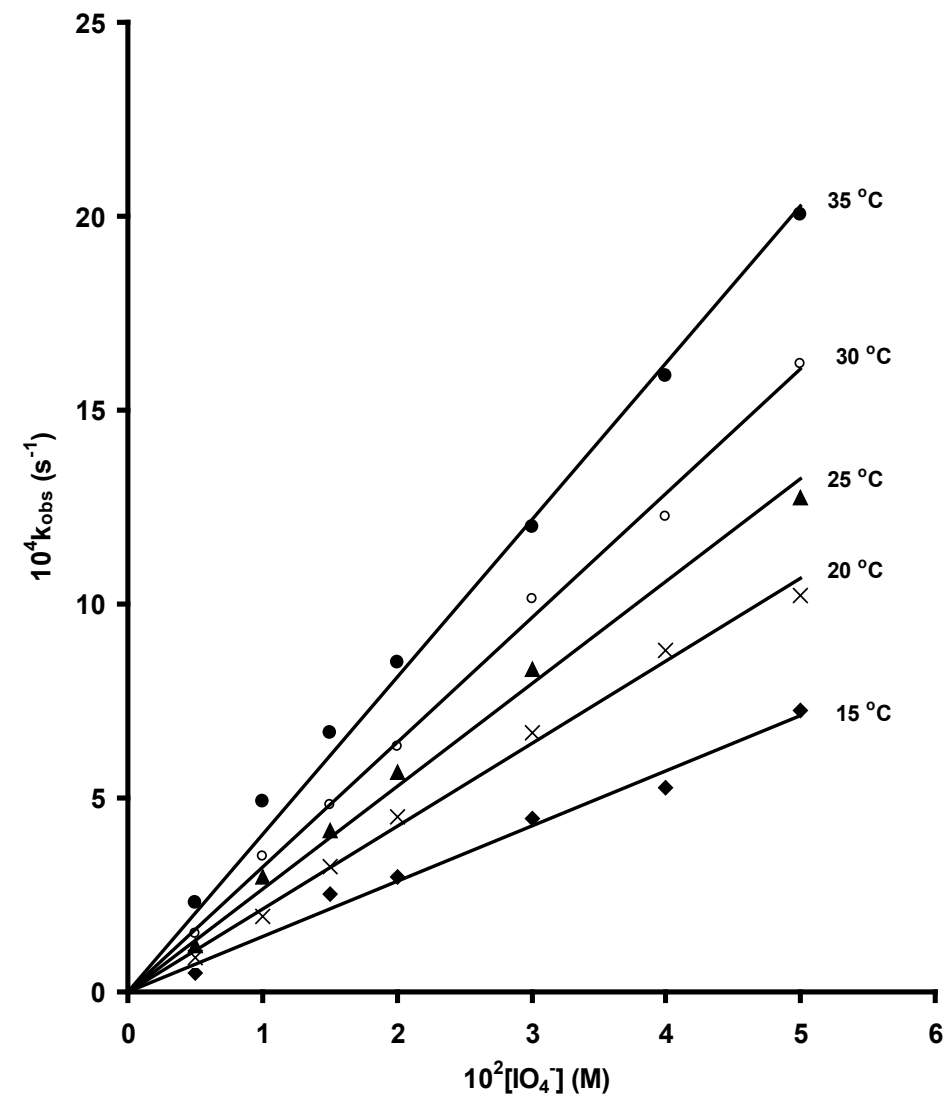

Figure 2. Plot of $k_{\text {obs }}$ versus $\left[\mathrm{IO}_{4}^{-}\right]$at different temperatures. 


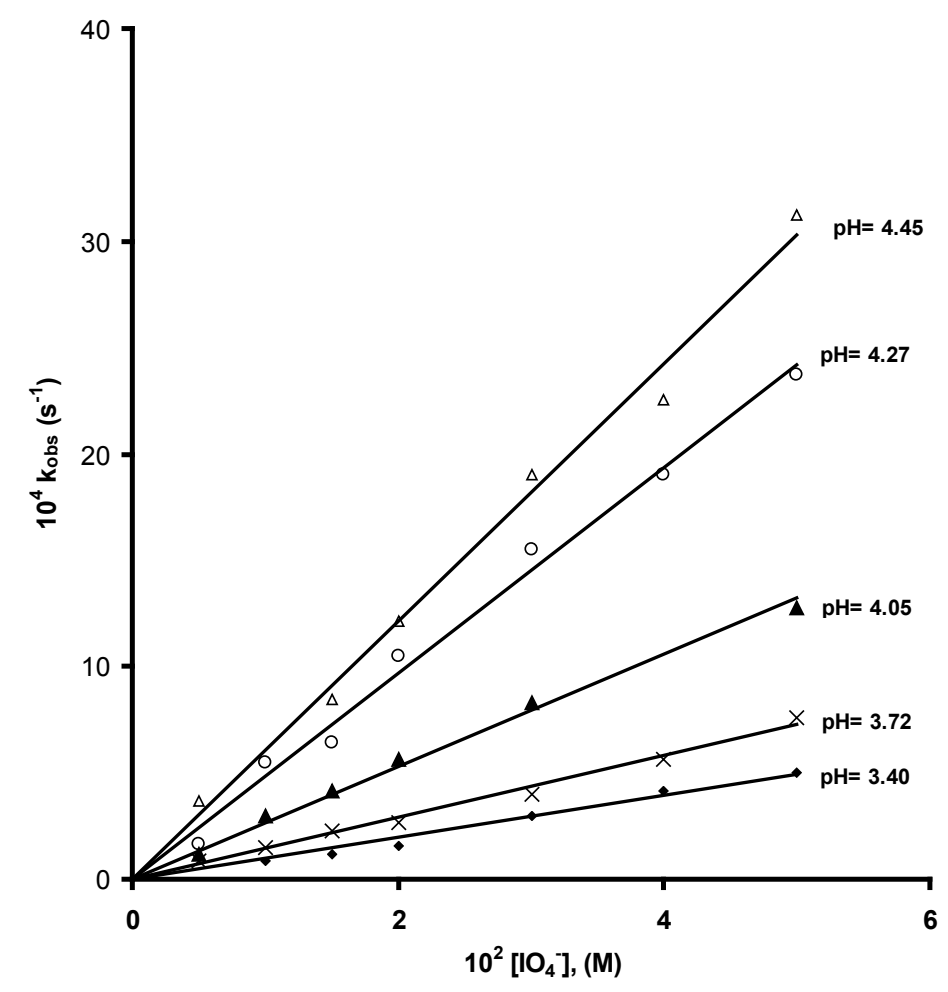

Figure 3. Plot of $k_{\text {obs }}$ versus $\left[\mathrm{IO}_{4}^{-}\right]$at different $\mathrm{pH}$.

The values of $k_{2}$ and $k_{3}$ were obtained from the intercept and slope as $4.28 \times$ $10^{-3} \mathrm{~mol}^{-1} \cdot \mathrm{dm}^{3} \cdot \mathrm{s}^{-1}$ and $2.09 \times 10^{-6} \mathrm{~s}^{-1}$ respectively at $T=25^{\circ} \mathrm{C}$.

From Equations (2), (3) and (4), the rate law for the oxidation of $\left[\mathrm{Cr}^{\text {III }}(\mathrm{NTA})(\mathrm{Ala})\left(\mathrm{H}_{2} \mathrm{O}\right)\right]^{-}$by periodate is given by Equation (5):

$$
\mathrm{d}\left[\mathrm{Cr}^{\mathrm{VI}}\right] / \mathrm{d} t=\left[\mathrm{IO}_{4}^{-}\right]\left[\mathrm{Cr}^{\mathrm{III}}(\mathrm{NTA})(\mathrm{Ala})\left(\mathrm{H}_{2} \mathrm{O}\right)\right]^{-}\left(k_{2}+k_{3} /\left[\mathrm{H}^{+}\right]\right)
$$

and

$$
k_{\text {obs }}=\left(k_{2}+k_{3} /\left[\mathrm{H}^{+}\right]\right)\left[\mathrm{IO}_{4}^{-}\right]
$$

Table 3 shows the values of $k_{1}$ which obtained from the slopes of Figure 2 at different temperatures. From these results, thermodynamic activation parameters $\Delta H^{\star}$ and $\Delta S^{*}$ associated with constant $\left(k_{1}\right)$ in Equation (3) were calculated using Eyring approximation. $\Delta H^{\star}$ and $\Delta S^{\star}$ are equal to $35.75 \mathrm{~kJ} \cdot \mathrm{mol}^{-1}$ and $-155.3 \mathrm{~J} \cdot \mathrm{K}^{-1} \cdot \mathrm{mol}^{-1}$ respectively. According to the data reported, The effect of hydrogen ion concentration was investigated over the $\mathrm{pH}$ range 3.40 - 4.45, we noticed that in acidic aqueous medium the chromium(III) complex may be involved in the equilibrium shown in Equation (7).

$$
\left[\mathrm{Cr}^{\mathrm{III}}(\mathrm{NTA})(\mathrm{Ala})\left(\mathrm{H}_{2} \mathrm{O}\right)\right]^{-} \rightleftharpoons\left[\mathrm{Cr}^{\mathrm{III}}(\mathrm{NTA})(\mathrm{Ala})(\mathrm{OH})\right]^{2-}+\mathrm{H}^{+} \quad K_{1}
$$

The value of $K_{1}$ can be determined potentiometrically and has the value $1.70 \times$ $10^{-5}$ at $25^{\circ} \mathrm{C}$. From the $\mathrm{pH}$ range and $K_{1}$ value, it may be suggested that the involvement of the deprotonated form of the chromium(III)-complex in the rate-determining step. There are possibilities for the coordination of $\mathrm{IO}_{4}^{-}$due 
to the following reasons. Firstly, the $\mathrm{H}_{2} \mathrm{O}$ ligand in $\left[\mathrm{Cr}^{\mathrm{III}}(\mathrm{NTA})(\mathrm{Ala})\left(\mathrm{H}_{2} \mathrm{O}\right)\right]^{-}$may be labile and hence substitution by $\mathrm{IO}_{4}^{-}$is likely [29] [30] [31]. Secondly, periodate ion is capable of acting as a ligand, as evidenced from its coordination to copper(III) [32] and nickel(IV) [33]. Also there is a direct relationship between the reaction rate and ionic strength, where the values of $10^{4} k_{\text {obs }}$ obtained at $I=$ $0.30,0.40,0.50$ and $0.60 \mathrm{~mol} \cdot \mathrm{dm}^{-3}, \mathrm{pH}=4.05,\left[\mathrm{IO}_{4}^{-}\right]=0.02 \mathrm{~mol} \cdot \mathrm{dm}^{-3}$ and $T=$ $25^{\circ} \mathrm{C}$ are $5.83,6.05,6.27$ and 6.57 , respectively which is attributed to the reaction between similar charged species. It may be concluded that from the reported equilibrium constants of aqueous periodate solutions over the $\mathrm{pH}$ range used that, the periodate species likely to be present are $\mathrm{IO}_{4}^{-}, \mathrm{H}_{4} \mathrm{IO}_{6}^{-}$and $\mathrm{H}_{3} \mathrm{IO}_{6}^{2-}$ [34], according to the equilibria, Equations (8)-(10):

$$
\begin{gathered}
\mathrm{H}_{5} \mathrm{IO}_{6} \rightleftharpoons \mathrm{H}_{4} \mathrm{IO}_{6}^{-}+\mathrm{H}^{+} \quad\left(K_{2}=1.98 \times 10^{-3} \mathrm{dm}^{3} \cdot \mathrm{mol}^{-1}\right) \\
\mathrm{H}_{4} \mathrm{IO}_{6}^{-} \rightleftharpoons 2 \mathrm{H}_{2} \mathrm{O}+\mathrm{IO}_{4}^{-} \quad\left(K_{3}=0.025\right) \\
\mathrm{H}_{4} \mathrm{IO}_{6}^{-} \rightleftharpoons \mathrm{H}_{3} \mathrm{IO}_{6}^{2-}+\mathrm{H}^{+} \quad\left(K_{4}=5.0 \times 10^{6} \mathrm{dm}^{3} \cdot \mathrm{mol}^{-1}\right)
\end{gathered}
$$

From $K_{4}$ value, $\mathrm{H}_{3} \mathrm{IO}_{6}^{2-}$ is not the predominant species ( $\mathrm{IO}_{4}^{-}$will be used to represent $\mathrm{H}_{4} \mathrm{IO}_{6}^{-}$).

The mechanistic pathway for the oxidation of nitrilotriacetatetrisodium salt chromium(III) complex by periodate over the studied $\mathrm{pH}$ range may be represented by Equations (11)-(23):

$$
\begin{aligned}
& {\left[\mathrm{Cr}^{\mathrm{III}}(\mathrm{NTA})\right.}\left.(\mathrm{Ala})\left(\mathrm{H}_{2} \mathrm{O}\right)\right]^{-} \rightleftharpoons\left[\mathrm{Cr}^{\mathrm{III}}(\mathrm{NTA})(\mathrm{Ala})(\mathrm{OH})\right]^{2-}+\mathrm{H}^{+} \quad K_{1} \\
& {\left[\mathrm{Cr}^{\mathrm{III}}(\mathrm{NTA})(\mathrm{Ala})\left(\mathrm{H}_{2} \mathrm{O}\right)\right]^{-}+\left[\mathrm{IO}_{4}^{-}\right] } \\
& \rightleftharpoons\left[\mathrm{Cr}^{\text {III }}(\mathrm{NTA})(\mathrm{Ala})\left(\mathrm{OIO}_{3}\right)\right]^{2-}+\mathrm{H}_{2} \mathrm{O} \quad K_{5} \\
& {\left[\mathrm{Cr}^{\mathrm{III}}(\mathrm{NTA})(\mathrm{Ala})(\mathrm{OH})\right]^{2-}+\left[\mathrm{IO}_{4}^{-}\right] } \\
& \rightleftharpoons\left[\mathrm{Cr}^{\mathrm{III}}(\mathrm{NTA})(\mathrm{Ala})(\mathrm{OH})\left(\mathrm{OIO}_{3}\right)\right]^{3-}\left(K_{6}\right) \\
& {\left[\mathrm{Cr}^{\mathrm{III}}(\mathrm{NTA})(\mathrm{Ala})\left(\mathrm{OIO}_{3}\right)\right]^{2-} \stackrel{k_{4}}{\longrightarrow} \text { Products } } \\
& {\left[\mathrm{Cr}^{\text {III }}(\mathrm{NTA})(\mathrm{Ala})\left(\mathrm{OIO}_{3}\right)(\mathrm{OH})\right]^{3-} \stackrel{k_{5}}{\longrightarrow} \text { Products } }
\end{aligned}
$$

From the above mechanism, the rate of the reaction is given by:

$$
\begin{aligned}
\mathrm{d}\left[\mathrm{Cr}^{\mathrm{VI}}\right] / \mathrm{d} t= & k_{4}\left[\mathrm{Cr}^{\mathrm{III}}(\mathrm{NTA})(\mathrm{Ala})\left(\mathrm{OIO}_{3}\right)\right]^{2-} \\
& +k_{5}\left[\mathrm{Cr}^{\mathrm{III}}(\mathrm{NTA})(\mathrm{Ala})(\mathrm{OH})\left(\mathrm{OIO}_{3}\right)\right]^{3-}
\end{aligned}
$$

Since

$$
\left[\mathrm{Cr}^{\mathrm{III}}(\mathrm{NTA})(\mathrm{Ala})\left(\mathrm{OIO}_{3}\right)\right]^{2-}=K_{5}\left[\mathrm{Cr}^{\mathrm{III}}(\mathrm{NTA})(\mathrm{Ala})\left(\mathrm{H}_{2} \mathrm{O}\right)\right]^{-}\left[\mathrm{IO}_{4}^{-}\right]
$$

and

$$
\left[\mathrm{Cr}^{\mathrm{III}}(\mathrm{NTA})(\mathrm{Ala})(\mathrm{OH})\left(\mathrm{OIO}_{3}\right)\right]^{3-}=K_{6}\left[\mathrm{Cr}^{\mathrm{III}}(\mathrm{NTA})(\mathrm{Ala})(\mathrm{OH})\right]^{2-}\left[\mathrm{IO}_{4}^{-}\right]
$$

Substitution in Equations (17) and (18) in Equation (16) leads to: 


$$
\begin{aligned}
\mathrm{d}\left[\mathrm{Cr}^{\mathrm{VI}}\right] / \mathrm{d} t= & K_{2} k_{4}\left[\mathrm{Cr}^{\mathrm{III}}(\mathrm{NTA})(\mathrm{Ala})\left(\mathrm{H}_{2} \mathrm{O}\right)\right]^{-}\left[\mathrm{IO}_{4}^{-}\right] \\
& +k_{5} K_{6}\left[\mathrm{Cr}^{\mathrm{III}}(\mathrm{NTA})(\mathrm{Ala})(\mathrm{OH})\right]^{2-}\left[\mathrm{IO}_{4}^{-}\right]
\end{aligned}
$$

Since

$$
\left[\mathrm{Cr}^{\mathrm{III}}(\mathrm{NTA})(\mathrm{Ala})(\mathrm{OH})\right]^{2-}=K_{1}\left[\mathrm{Cr}^{\mathrm{III}}(\mathrm{NTA})(\mathrm{Ala})\left(\mathrm{H}_{2} \mathrm{O}\right)\right]^{-} /\left[\mathrm{H}^{+}\right]
$$

Substitution Equation (20) in Equation (19) we obtained:

$$
\begin{aligned}
\mathrm{d}\left[\mathrm{Cr}^{\mathrm{VI}}\right] / \mathrm{d} t= & K_{5} k_{4}\left[\mathrm{Cr}^{\mathrm{III}}(\mathrm{NTA})(\mathrm{Ala})\left(\mathrm{H}_{2} \mathrm{O}\right)\right]^{-}\left[\mathrm{IO}_{4}^{-}\right] \\
& +\left(k_{5} K_{6} K_{1} /\left[\mathrm{H}^{+}\right]\right)\left[\mathrm{Cr}^{\mathrm{III}}(\mathrm{NTA})(\mathrm{Ala})\left(\mathrm{H}_{2} \mathrm{O}\right)\right]^{-}\left[\mathrm{IO}_{4}^{-}\right]
\end{aligned}
$$

On rearrangement:

$$
\mathrm{d}\left[\mathrm{Cr}^{\mathrm{VI}}\right] / \mathrm{d} t=\left(k_{4} K_{5}+k_{5} K_{6} K_{1} /\left[\mathrm{H}^{+}\right]\right)\left[\mathrm{Cr}^{\mathrm{III}}(\mathrm{NTA})(\mathrm{Ala})\left(\mathrm{H}_{2} \mathrm{O}\right)\right]^{-}\left[\mathrm{IO}_{4}^{-}\right]
$$

Hence,

$$
k_{\text {obs }}=\left[\mathrm{IO}_{4}^{-}\right]\left\{k_{4} K_{5}+\left(k_{5} K_{1} K_{6} /\left[\mathrm{H}^{+}\right]\right)\right\}
$$

From a comparison of Equations (6) and (23) one obtains $k_{2}=k_{4} K_{5}$ and $k_{3}=$ $k_{5} K_{1} K_{6}$. Equation (23) contains two terms, first term represents path independent of $\left[\mathrm{H}^{+}\right]$and the second term represents path dependent on $\left[\mathrm{H}^{+}\right]$. In comparison with the oxidation of $\left[\mathrm{Cr}(\mathrm{NTA})\left(\mathrm{H}_{2} \mathrm{O}\right)_{2}\right]$ [23] under the same conditions, the deprotonated complexes are significantly found to be more reactive than their conjugate acids. The rate of oxidation of this $\left[\mathrm{Cr}(\mathrm{NTA})\left(\mathrm{H}_{2} \mathrm{O}\right)_{2}\right]$ is more than $\left[\mathrm{Cr}^{\text {III }}(\mathrm{NTA})(\mathrm{Ala})\left(\mathrm{H}_{2} \mathrm{O}\right)\right]^{-}$This means that the stability of the ternary complex, $\left[\mathrm{Cr}^{\mathrm{III}}(\mathrm{NTA})(\mathrm{Ala})\left(\mathrm{H}_{2} \mathrm{O}\right)\right]^{-}$, is more than the binary one, $\left[\mathrm{Cr}(\mathrm{NTA})\left(\mathrm{H}_{2} \mathrm{O}\right)_{2}\right]$, toward oxidation. This may be due to the presence of the amino acid as a secondary ligand in the ternary complex, increase the stability of chromium(III) towards oxidation than binary complex, $\left[\mathrm{Cr}^{\mathrm{III}}(\mathrm{NTA})\left(\mathrm{H}_{2} \mathrm{O}\right)_{2}\right]$.

The small $\Delta H^{\star}$ values and large negative activation entropies reasonably could reflect some nonadibatically in the electron transfer process [35]. Both $\Delta H^{*}$ and $\Delta S^{*}$ then may be expected to systematically increases as the orientation of the oxidant in the precursor complex is alter so as to enhance overlap between donor and acceptor redox orbitals and consequently the probability of adiabatic electron transfer [35]. The relatively low value of $\Delta H^{\star}$ for $\left[\mathrm{Cr}^{\text {III }}(\mathrm{NTA})(\mathrm{Ala})\left(\mathrm{H}_{2} \mathrm{O}\right)\right]^{-}$is due to its composite value including formation which may be exothermic and intramolecular electron transfer which may be endothermic.

Enthalpies and entropies of activation for the oxidation of chromium(III) complexes by periodate are collected in Table $4 . \Delta H^{\star}$ and $\Delta S^{\star}$ for the oxidation of these complexes were calculated related to intramolecular electron transfer steps except for $\left[\mathrm{Cr}^{\mathrm{III}}(\mathrm{HIDA})_{2}\left(\mathrm{H}_{2} \mathrm{O}\right)\right]$, and $\left[\mathrm{Cr}^{\mathrm{III}}(\mathrm{NTA})(\mathrm{Hist})\left(\mathrm{H}_{2} \mathrm{O}\right)\right]^{-}, \Delta H^{\star}$ and $\Delta S^{*}$ are composite values including the enthalpy of formation of the precursor complexes and the intramolecular electron transfer steps. A plot of $\Delta H^{\star}$ versus $\Delta S^{*}$ for these complexes is shown in Figure 4, and an excellent linear relationship 
Table 4. Enthalpies and entropies of activation for the oxidation of chromium(III) complexes by periodate.

\begin{tabular}{|c|c|c|c|c|c|}
\hline Complex & $\begin{array}{l}10^{3} k^{\mathrm{et}} \\
\left(\mathrm{s}^{-1}\right)\end{array}$ & $\begin{array}{c}\Delta H^{\star} \\
(\mathrm{KJ} / \mathrm{mol})\end{array}$ & $\begin{array}{c}-\Delta S^{*} \\
(\mathrm{~J} / \mathrm{Kmol})\end{array}$ & Ref. & $\begin{array}{c}\text { Figure } 4 \\
\text { key }\end{array}$ \\
\hline$\left[\mathrm{Cr}^{\mathrm{III}}(\mathrm{TOH})\left(\mathrm{H}_{2} \mathrm{O}\right)\right]$ & 2.95 & 76 & 38.7 & 29 & 1 \\
\hline$\left[\mathrm{Cr}^{\mathrm{III}}(\mathrm{NTA})(\mathrm{Asp})\left(\mathrm{H}_{2} \mathrm{O}\right)\right]^{-}$ & 3.93 & 64.6 & 76 & 13 & 2 \\
\hline$\left[\mathrm{Cr}^{\mathrm{III}}(\mathrm{Ud})(\mathrm{Asp})\left(\mathrm{H}_{2} \mathrm{O}\right)_{3}\right]^{2+}$ & 0.70 & 59.5 & 106.8 & 16 & 3 \\
\hline$\left[\mathrm{Cr}^{\mathrm{III}}(\mathrm{NTA})(\text { Hist })\left(\mathrm{H}_{2} \mathrm{O}\right)\right]^{-}$ & 32.00 & 36.5 & 148 & 13 & 4 \\
\hline$\left[\mathrm{Cr}^{\mathrm{III}}(\mathrm{NTA})(\mathrm{Ala})\left(\mathrm{H}_{2} \mathrm{O}\right)\right]^{-}$ & 26.40 & 35.75 & 155.3 & $\begin{array}{l}\text { This } \\
\text { work }\end{array}$ & 5 \\
\hline$\left[\mathrm{Cr}^{\mathrm{III}}(\mathrm{Arg})_{2}\left(\mathrm{H}_{2} \mathrm{O}\right)_{2}\right]^{+}$ & 3.46 & 30 & 192 & 13 & 6 \\
\hline$\left[\mathrm{Cr}^{\mathrm{III}}(\mathrm{NTA})\left(\mathrm{H}_{2} \mathrm{O}\right)_{2}\right]$ & 62.00 & 14 & 220 & 23 & 7 \\
\hline$\left[\mathrm{Cr}^{\mathrm{III}}(\mathrm{HIDA})_{2}\left(\mathrm{H}_{2} \mathrm{O}\right)\right]$ & 10.90 & 12.3 & 240.7 & 25 & 8 \\
\hline
\end{tabular}

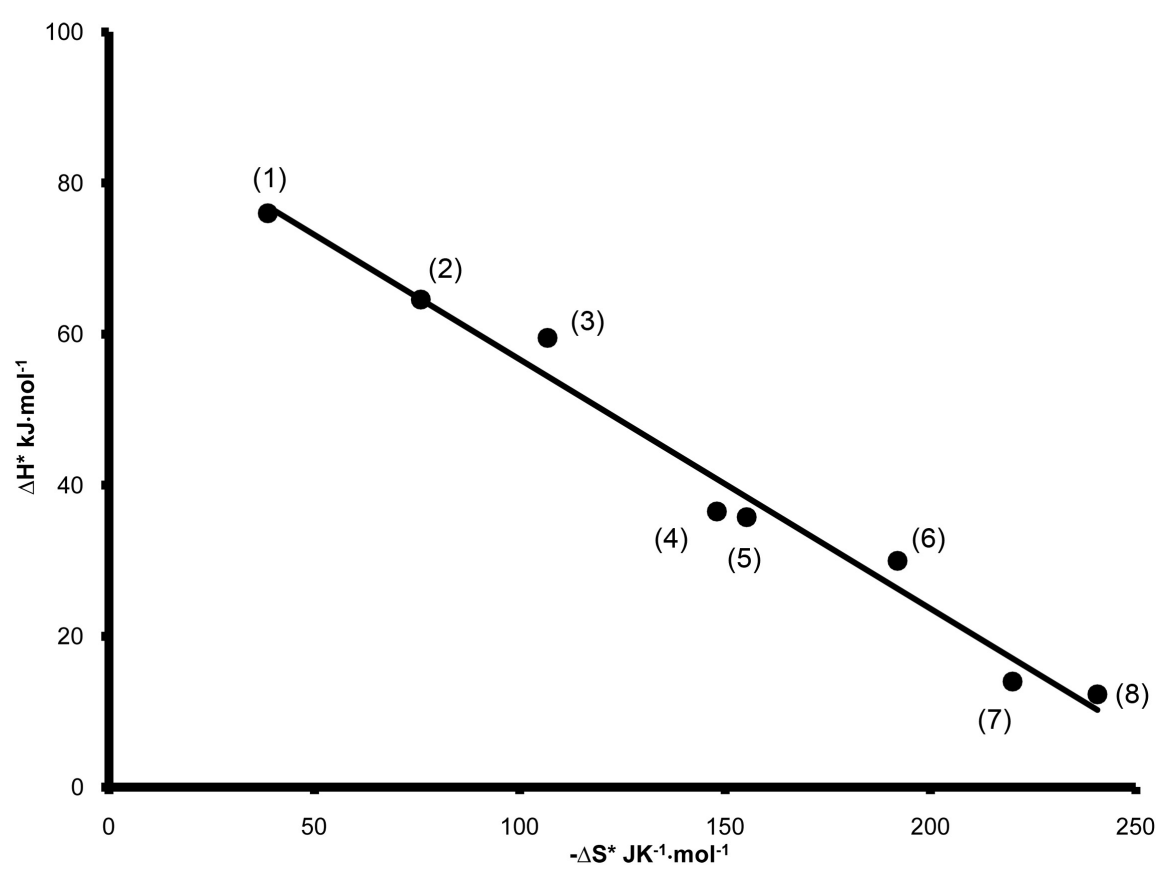

Figure 4. Enthalpies and entropies of activation of some chromium(III) complexes.

was obtained. Similar linear plots were found for a large number of redox reactions [36] [37] and for each reaction series a common rate-determining step is proposed. The isokinetic relation lends support a common mechanism for the oxidation of chromium(III) complexes, reported here, by periodate.

This consists of a periodate ion coordination to the chromium(III) complexes in step preceding the rate-determining intramolecular electron transfer within the precursor complex. Isokinetic compensation between $\Delta H^{*}$ and $\Delta S^{*}$ in a series of related reactions usually implies that one interaction between the reactants varies within the series, the remainder of the mechanism being invariant [32]. The electron transfer reactivities of these complexes with periodate are comparable, as the coordination of periodate with these complexes are identical. All of 
this suggests that the excellent correlation often observed between $\Delta S^{*}$ and $\Delta H^{\star}$ mainly reflects the fact that both thermodynamic parameters are in reality two measures of the same thing, and that measuring a compensation temperature is just a rather indirect way of measuring the average temperature at which the experiments were carried out. As this temperature will often be in a range that the experimenter expects to have some biological significance, it is not surprising if the compensation temperature turns out to have a biologically suggestive value [38] [39] [40].

\section{Conclusion}

Oxidation of $\left[\mathrm{Cr}^{\text {III }}(\mathrm{NTA})(\mathrm{Ala})\left(\mathrm{H}_{2} \mathrm{O}\right)\right]^{-}$by periodate proceeds via an inner-sphere mechanism. Rate of oxidation increases with increasing $\mathrm{pH}$. These reactions proceed through two-electron transfer process leading to the formation of chromium(VI). A common mechanism for the oxidation of ternary chromium(III) complex by periodate is proposed, and is supported by the excellent isokinetic relationship between $\Delta H^{\star}$ and $\Delta S^{\star}$ values for these reactions.

\section{Conflicts of Interest}

The authors declare no conflicts of interest regarding the publication of this paper.

\section{References}

[1] Sigel, H. (1980) Ternary Complexes in Solution. 34. Discriminating and Stability increasing Properties of the Imidazole Moiety in Mixed-Ligand Complexes. Inorganic Chemistry, 19, 1411. https://doi.org/10.1021/ic50207a069

[2] Sigel, H., Operschall, B.P., Massoud, S.S., Song, B. and Griesser, R. (2006) Evidence for Intramolecular Aromatic-Ring Stacking in the Physiological $\mathrm{pH}$ Range of the Monodeprotonated Xanthine Residue in Mixed-Ligand Complexes Containing Xanthosinate 5'-monophosphate (XMP). Dalton Transactions, 46, 5521. https://pubs.rsc.org/en/content/articlelanding/2006/dt/b610082a\#!divAbstract https://doi.org/10.1039/B610082A

[3] Arnold, H.F. (1991) Metal-Affinity Separations: A New Dimension in Protein Processing. Bio/Technology, 9,151. https://www.nature.com/articles/nbt0291-151

[4] Roginski, E.E. and Mertz, W. (1969) Effects of Chromium(III) Supplementation on Glucose and Amino Acid Metabolism in Rats Fed a Low Protein Diet. The Journal of Nutrition, 97, 525.

https://academic.oup.com/jn/article-abstract/97/4/525/4776397?redirectedFrom=ful $\underline{\text { ltext }}$ https://doi.org/10.1093/jn/97.4.525

[5] Levina, A. and Lay, P. (2008) Chemical Properties and Toxicity of Chromium(III). Chemical Research in Toxicology, 21, 563-571. https://doi.org/10.1021/tx700385t

[6] Levina, A. and Lay, P.A. (2005) Mechanistic Studies of Relevance to the Biological Activities of Chromium. Coordination Chemistry Reviews, 249, 281.

https://www.sciencedirect.com/science/article/pii/S0010854504000438 https://doi.org/10.1016/j.ccr.2004.02.017

[7] Lilian, J., Yanjie, S., Jason, H., Weiwei, G., Stephen, P.C., Michael, W., Gary, A. L., 
John, B.V. and Jean-Marc, L. (2003) Characterization of Chromodulin by X-Ray Absorption and Electron Paramagnetic Resonance Spectroscopies and Magnetic Susceptibility Measurements. Journal of the American Chemical Society, 125, 774. https://doi.org/10.1021/ja0202661

[8] Tiziani, S., Sussich, F. and Cesaro, A. (2003) The Kinetics of Periodate Oxidation of Carbohy Drates 2, Polymeric Substrates. Carbohydrate Research, 338, 1083. https://www.sciencedirect.com/science/article/pii/S000862150300082X https://doi.org/10.1016/S0008-6215(03)00082-X

[9] Bassil, D., Makris, D.P. and Kefalas, P. (2005) Oxidation of Caffeic Acid in the Presence of L-Cysteine: Isolation of 2-S-Cysteinylcaffeic Acid and Evaluation of Its Antioxidant Properties. Food Research International, 38, 395.

https://www.sciencedirect.com/science/article/pii/S0963996904002297 https://doi.org/10.1016/j.foodres.2004.10.009

[10] Mirkhani, V., Tangestaninejad, S., Moghadom, M. and Moghbel, M. (2004) Cytochrome P-450 Dependent Monooxygenases Model System: Rapid and Efficient Oxidation of Primary Aromatic Amines to Azo Derivatives with Sodium Periodate Catalyzed by Manganese(III) Schiff Base Complexes. Bioorganic \& Medicinal Chemistry, 12, 4673.

https://www.sciencedirect.com/science/article/pii/S0968089604004742 https://doi.org/10.1016/j.bmc.2004.06.029

[11] Ewais, H.A. and Ismail, M.I. (2013) Mechanism of Electron Transfer Reaction of Ternary Dipicolinatochromium(III) Complex Involving Oxalate as Secondary Ligand. Journal of Chemical Sciences, 125, 1152-1159.

https://doi.org/10.1007/s12039-013-0491-x

[12] Abdel-Khalek, A.A., Sayyah, S.M. and Ewais, H.A. (1997) Kinetics and Mechanism of Oxidation of the chromium(III)-dl-valine Complex/Periodate Reaction. Evidence for Iron(II) Catalysis. Transition Metal Chemistry, 22, 375.

https://link.springer.com/article/10.1023/A\%3A1018518019925\#citeas https://doi.org/10.1023/A:1018518019925

[13] Ewais, H.A., Habib, M.A. and Elroby, S.A.K. (2010) Kinetics and Mechanism of Periodate Oxidation of Two Ternary Nitrilotriacetatochromium(III) Complexes Involving Histidine and Aspartate Co-Ligands. Transition Metal Chemistry, 35, 73. https://link.springer.com/article/10.1007/s11243-009-9297-6 https://doi.org/10.1007/s11243-009-9297-6

[14] Ewais, H.A., Ahmed, S.A. and Abdel-Khalek, A.A. (2004) Kinetics and Mechanism of Oxidation of Chromium(III) Complex of Gaunosine by Periodate. Inorganic Reaction Mechanism, 5, 125.

[15] Abdel-Khalek, A.A., Ewais, H.A. and Ahmed, S.A. (2004) Kinetics and Mechanism of Oxidation of Chromium(III)-Guanosine 5-Monophosphate Complex by Periodate. Journal of the Chinese Chemical Society, 51, 713. https://onlinelibrary.wiley.com/doi/abs/10.1002/jccs.200400108 https://doi.org/10.1002/jccs.200400108

[16] Khaled, S.E. (2006) Inner-Sphere Oxidation of Binary and Ternary Uridine Chromium(III) Complexes Involving Aspartate by Periodate. Inorganic Reaction $\mathrm{Me}$ chanisms, 6, 247-256.

[17] Ewais, H.A. (2008) Mechanism of Electron Transfer Reaction of Ternary Nitrilotriacetatocobalt(II) Complexes Involving Succinate and Malonate as Secondary Ligands. International Journal of Chemical Kinetics, 40, 103. https://onlinelibrary.wiley.com/doi/abs/10.1002/kin.20289 https://doi.org/10.1002/kin.20289 
[18] Abdel-Khalek, A.A., Khaled, E.S.H. and Mohamed, R.A. (2007) Kinetics Mechanism of Electron Transfer Reactions of Ternary Nitrilotriacetatocobaltate(II) Complexes Involving Maleate and Tartarate by Periodate. Journal of Coordination Chemistry, 61, 152-161. https://doi.org/10.1080/00958970701310902

[19] Ewais, H.A. (2009) Kinetics and Mechanism of the Oxidation of a Ternary Complex of Cobalt(II) Involving Nitrilotriacetate and Benzoate by Periodate in Acetate Medium. Evidence for Manganese(II) as a Catalyst. Journal of Coordination Chemistry, 62, 152. https://www.tandfonline.com/doi/full/10.1080/00958970802381190 https://doi.org/10.1080/00958970802381190

[20] Naik, R.M., Sarker, J., Chaturvedi, D.D., Verma, A. and Singh, S.K. (2003) Kinetics of Oxidation of Cobalt(II) Complexes of Propylenediaminetetraacetate and 1,3-diamino2-hydroxyprpanetetra Acetate by Periodate. Indian Journal of Chemistry Section A, 42, 1639-1647. http://hdl.handle.net/123456789/20691

[21] Abu-Elenien, M.H., Al-Shatti, N.I., Hussein, M.A. and Sulfab, Y. (1990) Kinetics and Mechanism of the Oxidation of Diethylenetriaminepentaacetatocobaltate(II) by Periodate. Polyhedron, 9, 99-105.

https://www.sciencedirect.com/science/article/pii/S0277538700842527

[22] Naik, R.M., Srivastava, A., Tiwari, A.K., Yadav, S.B.S. and Verma, A.K. (2007) Kinetic and Mechanistic Studies of Oxidation of Amine-N-Polycarboxylates Complexes of Cobalt(II) by Periodate Ions in Aqueous Medium. Journal of the Iranian Chemical Society, 4, 63-71. https://link.springer.com/article/10.1007/BF03245804

[23] Abdel-Khalek, A.A. and Elsemongy, M.M. (1989) Kinetics of the Oxidation of Diaqua(nitrilotriacetato)-Chromium(III) by Periodate in Aqueous Solutions. Transition Metal Chemistry, 14, 206-208. https://doi.org/10.1007/BF01043796 https://link.springer.com/article/10.1007/BF01043796

[24] Abdel-Hady, A.M. (2000) Kinetics of Oxidation of a 2-Aminomethyl Pyridine Chromium (III) Complex by Periodate. Transition Metal Chemistry, 25, 437-442. https://link.springer.com/article/10.1023/A\%3A1007019528319 https://doi.org/10.1023/A:1007019528319

[25] Ewais, H.A., Al-Otaibi, F.D. and Abdel-Khalek, A.A. (2006) Kinetics and Mechanism of Oxidation of Iminodiacetatochromium(III) by Periodate. Inorganic Reaction Mechanisms, 6, 39-47.

[26] Sharma, C.L., Jain, P.K. and De, T.K. (1980) Preparation and Characterization of Some mixed Ligand Complexes of Chromium Nitrilotriacetate with Some Amino Acids. Inorganic Nuclear Chemistry, 42, 1681-1687. https://ac.els-cdn.com/0022190280801394/1-s2.0-0022190280801394-main.pdf

[27] Symons, M.C.R. (1955) Photochemical Decomposition of Periodate. Journal of the Chemical Society, 2794-2799. https://doi.org/10.1039/jr9550002794

[28] Irving, H.M. and Rossotti, H.S. (1953) The Calculation of Formation Curves of Metal Complexes from $\mathrm{pH}$ Titration Curves in Mixed Solvents. Journal of the Chemical Society, 2904-2910. https://doi.org/10.1039/jr9530003397 https://pubs.rsc.org/en/content/articlelanding/1954/jr/jr9540002904\#!divAbstract

[29] Abdel Khalek, A.A., Sayyah, S.M. and Abdel-Hameed, F.F. (1994) Kinetics and Mechanism of Oxidation of Chromium(III)-Tetraoxalylurea Complex by Periodate. Transition Metal Chemistry, 19, 108-110. https://doi.org/10.1007/BF00166281 https://link.springer.com/article/10.1007/BF00166281

[30] Amal, S., Basaleh, A. and Abdel-Salam, H. (2016) Inner-Sphere Oxidation of a Ternary Dipicolinatochromium(III) Complex Involving a Malonic Acid Co-Ligand. Transition Metal Chemistry, 41, 713-719. 
https://doi.org/10.1007/s11243-016-0073-0

https://link.springer.com/article/10.1007\%2Fs11243-016-0073-0

[31] Hassan, A., Ewais, R., Al-Orabi, O. and Obaid, A.Y. (2016) Manganese(II) Catalyzed Periodate Oxidation of a Ternary Dipicolinatochromium(III) Complex with Iminodiacetate as Co-Ligand: Mechanistic and Kinetic Study. Transition Metal Chemistry, 41, 427-434. https://doi.org/10.1007/s11243-016-0038-3 https://link.springer.com/article/10.1007/s11243-016-0038-3

[32] Hadince, I., Jenosovsky, L., Linek, A. and Synecek, V. (1960) Über die Struktur der komplexen Perkuprate. Naturwiss, 47, 377. https://link.springer.com/article/10.1007/BF00631384

[33] Ray, P. (1957) Sodium and Potassium Nickel (IV) Paraperiodates. Inorganic Synthesis, 5, 201-208.

[34] Crouthamel, C.E., Meek, H.V., Martin, D.S. and Banks, C.V. (1949) Spectrophotometric Studies of Dilute Aqueous Periodate Solutions. Journal of the American Chemical Society, 71, 3031-3035. https://pubs.acs.org/doi/10.1021/ja01177a026 https://doi.org/10.1021/ja01177a026

[35] Mcardle, J.V., Coyle, C.L., Gray, H.B., Yoneda, C.S. and Howerda, R.A. (1977) Kinetics Studies of the Oxidation of Blue Copper Proteins by Tris(1,10-phenanthroline)-Cobalt(III) Ions. Journal of the American Chemical Society, 99, 2483-2489. https://pubs.acs.org/doi/10.1021/ja00450a014 https://doi.org/10.1021/ja00450a014

[36] Holwerda, R.A. and Clemmer, J.D. (1979) Isokinetic Relationship in the Oxidation of Cuprous Stellacyanin by Cobalt(III) Complexes. Bioinorganic Chemistry, 11, 7-15. https://www.sciencedirect.com/science/article/pii/S0162013400800483

[37] Wherland, S. and Gray, H.B. (1977) Biological Aspects of Inorganic Chemistry. Wiley, New York, 189.

[38] Bowden, A.C. (2002) Enthalpy-Entropy Compensation: A Phantom Phenomenon. Journal of Biosciences, 27, 121-126. https://doi.org/10.1007/BF02703768 https://link.springer.com/article/10.1007/BF02703768

[39] Abu-Gharib, E.A., EL-Khatib, R.M., Nassr, L.A.E. and Abu-Dief, A.M. (2011) Kinetics of Base Hydrolysis of Some Chromen-2-One Indicator Dyes in Different Solvents at Different Temperatures. Journal of the Korean Chemical Society, 55, 346-353. https://doi.org/10.5012/jkcs.2011.55.3.346

[40] Abu-Gharib, E.A., EL-Khatib, R.M., Nassr, L.A.E. and Abu-Dief, A.M. (2017) Kinetics, Reactivity, Initial-Transition State Analysis and Thermodynamic Parameters of Base-Catalyzed Hydrolysis of Coumalic Acid in Solvents with Different Polarities. Arabian Journal of Chemistry, 10, S988-S995.

https://www.sciencedirect.com/science/article/pii/S1878535213000117 